\title{
EVALUATION OF POLYMERASE CHAIN REACTION FOR RAPID DIAGNOSIS OF CLINICALLY SUSPECTED TUBERCULOUS PLEURISY
}

\author{
Dil-Afroze*, Dinesh Sharma, G.N.Dhobi, Sonaullah Shah, Rafiqa Eachkoti, Ishraq Hussain*, \\ Zafar A. Shah* and Mushtaq A.Siddiqi*
}

Departments of Medicine, Immunology \& Molecular Medicine*,

Sher-I-Kashmir Institute of Medical Sciences, Soura, J\&K-190011 India.

\begin{abstract}
Pleural effusion is one of the commonest presentations of tuberculosis, the clinical manifestations being typically abrupt resembling bacterial pneumonia. Since delayed hypersensitivity is the underlying immune response, bacterial load is very low. Owing to these facts, tuberculous pleurisy as an extra-pulmonary disease poses a diagnostic dilemma. The conventional bacteriological methods rarely detectMycobacterium tuberculosis in pleural fluid and are of limited use in diagnosis of tuberculous pleurisy. We evaluated the efficacy of polymerase chain reaction (PCR) in the diagnosis of tuberculous pleurisy by targeting the gene segment coding for MPB64 protein specific for Mycobacterium tuberculosis. Based on the clinical criteria, 82 patients with lymphocytic exudative pleural effusion were included in the study. Patients were analyzed in two groups; one group consisting of 48 patients of tubercular pleural effusion confirmed by various diagnostic procedures and another group of 34 patients comprising of non-tubercular pleural effusion. There were no false positive results by PCR and the specificity worked out to be $100 \%$. Twenty two patients tested positive for Mantoux with a sensitivity of $45 \%$. $Z N$-staining for $A F B$ was found in samples from 15 patients (20\% sensitivity). ADA was positive for 28 patients with a sensitivity of $53 \%$. PCR was positive for $32 / 48$ patients (67\% sensitivity). Thus, PCR was found to be more sensitive than any other conventional method in diagnosis of clinically suspected tubercular pleurisy.
\end{abstract}

\section{KEY WORDS}

Polymerase chain reaction, Mycobacterium tuberculosis, MPB64, tubercular pleurisy

\section{INTRODUCTION}

A recent WHO survey has estimated that tuberculosis has emerged as the leading cause of death from a single infectious agent in the world and 7 to 8 million new tuberculosis cases add up each year. India alone comprises nearly $30 \%$ of the global burden of tuberculosis and approximately 2 million people die from the disease (2). In many parts of the world, tuberculosis remains the most common cause of pleural effusion (3) and involves nearly one in 30 patients. Except for tubercular emphysema, the bacterial load in the pleural effusion of tubercular pleurisy is very low. Owing to this fact, the

\section{Address for Correspondence:}

Dr. Mushtaq A.Siddiqi

Professor \& Head

Department of Immunology \& Molecular Medicine

Sher-I-Kashmir Institute of Medical Sciences,

Soura, J\&K-190011 India.

E-mail : siddiqimushtaq@yahoo.co.in reliability on conventional methods of laboratory diagnosis like AFB smear is very low $(4,5)$. In such clinical dilemma, a more rapid, sensitive and specific tool like the polymerase chain reaction is an added windfall, which yields results even with low microbial load (6).

The sensitivity and specificity of PCR as a diagnostic tool for timely diagnosis of clinically suspected tuberculous pleurisy has been varying in different studies done previously. Sritharan et al (1994) reported the sensitivity and specificity of PCR for the diagnosis of tuberculosis as $97 \%$ and $100 \%$ respectively (7). However, study done by Villen et al in 1998 reported that PCR was much less accurate. In their study PCR was positive in $42 \%$ of patients (8). The present study was conducted by targeting the MPB64 gene (1) specific for Mycobacterium tuberculosis to evaluate the efficacy of PCR as a diagnostic tool by determining the sensitivity and specificity of the detection of tubercular pleural effusion cases in the Kashmir valley. 


\section{MATERIALS AND METHODS Clinical specimens}

Based on the clinical criteria, patients with lymphocytic exudative pleural effusion admitted in the tertiary care cum referral centre at Sher-I-Kashmir Institute of Medical Sciences, Srinagar were recruited for the study which was carried out over a period of two years from May, 2002 to April, 2004. Ethical clearance from the IEC of the institute and patients' consent was sought before their inclusion in the study. Detailed history was taken and physical examination was performed according to the prescribed proforma. Routine laboratory investigations including Hemogram, ESR, KFT, LFT, Blood glucose, X-ray chest, ECG and Mantoux test were done for all the patients. Diagnostic thoracocentesis was also done for all the patients. Eighty-two patients (age 13-72 years) with lymphocytic exudative pleural effusion were included in the study. Patients were analyzed in two groups; one group consisting of 48 patients of tubercular pleural effusion with a strong clinical, radiological and histopathological evidence of tuberculosis including clinical response to antitubercular treatment and another group of 34 patients comprising of nontubercular pleural effusion. 3-4 ml of pleural effusion samples were collected from the eighty-two patients enlisted for this study. Pleural fluid analysis was done for presence of malignant cells and AFB staining. ADA activity of pleural fluid and CT scan chest were also carried out for the patients to establish diagnosis.

\section{Bacteriological examination of the pleural effusion samples}

Ziehl-Neelsen (Z-N) staining of smears was performed for all pleural effusion samples.

\section{Polymerase chain reaction}

PCR was performed in three different areas of the laboratory physically separated from each other as a precaution to avert cross-contamination.

\section{Sample processing for DNA}

DNA was extracted from pleural effusion samples following a modification of the protocol of Seth et al (9) by centrifugation at $3000 \mathrm{rpm}$ for $30 \mathrm{~min}$. followed by treating $200 \mu \mathrm{l}$ of the sediment with equal volume of lysis buffer (consisting of $0.2 \mathrm{M}$ $\mathrm{NaOH}, 2 \mathrm{M} \mathrm{NaCl}$ and $1 \%$ SDS) and $100 \mu \mathrm{g}$ proteinase- $\mathrm{K}$ at $60^{\circ} \mathrm{C}$ for 1 hour followed by $95^{\circ} \mathrm{C}$ for $15 \mathrm{~min}$. to inactivate proteinase $-\mathrm{K}$. The lysate was extracted successively with chloroform. The aqueous phase was adjusted to $0.3 \mathrm{M}$ sodium acetate ( $\mathrm{pH}$ 5.2), precipitated with ethanol and dissolved in double distilled water.

\section{Oligonucleotide primers}

The target for the PCR assay was MPB64 gene (1) which codes for an immunogenic protein specific to Mycobacterium tuberculosis complex. The sequences of the two primers used were:

Forward primer (460-479) Reverse primer (700-681) 5'-TCCGCTGCCAGTCGTCTTCC-3' 5'-GTCCTCGCGAGTCTAGGCCA-3'

\section{Amplification reaction}

DNA amplification by PCR was performed in the total reaction volume of $25 \mu \mathrm{l}$ with $5 \mu \mathrm{l}$ of extracted DNA, $10 \mathrm{mM}$ Tris- $\mathrm{Cl}(\mathrm{pH}$ 8.3), $1.5 \mathrm{mM} \mathrm{MgCl}_{2}, 50 \mathrm{mM} \mathrm{NaCl}$, gelatin $0.01 \%(\mathrm{w} / \mathrm{v}), 100 \mu \mathrm{M}$ of each dNTP (Genei-India), $0.5 \mu \mathrm{M}$ of each primer \& 0.5 Units of Taq polymerase (Genei-India). Amplification was carried out on a programmable Minicycler ${ }^{\mathrm{TM}}$ (MJ Research, USA). Initial denaturation at $94^{\circ} \mathrm{C}$ for $5 \mathrm{~min}$. was proceeded by 30 cycles each of denaturation $\left(94^{\circ} \mathrm{C}\right.$ for $30 \mathrm{sec}$.), annealing $\left(60^{\circ} \mathrm{C}\right.$ for $1 \mathrm{~min})$ and extension $\left(72^{\circ} \mathrm{C}\right.$ for $\left.2 \mathrm{~min}\right)$ followed by a final extension at $72^{\circ} \mathrm{C}$ for $7 \mathrm{~min}$.

\section{Detection and identification of amplified product}

The amplified product was electrophoresed into $2 \%$ agarose gels. The gels were stained with ethidium bromide and visualized in a UV-transilluminator (Vilber Lourmat, France). The presence of a $240 \mathrm{bp}$ fragment indicated a positive test (Fig. 1).

\section{RESULTS AND DISCUSSION}

In our study, based on the clinical criteria, 82 patients with lymphocytic exudative pleural effusion included in the study were analysed for tubercular pleural effusion. Twenty-two patients tested positive for Mantoux with a sensitivity of $45 \%$ (Table No.1). ZN-staining for AFB (Table No.1) was found in samples from 15 patients ( $20 \%$ sensitivity). ADA was positive for 28 patients with a sensitivity of $53 \%$ (Table No.1).

Mycobacterium tuberculosis specific MPB64 targeted sequence was detected in pleural effusion samples from 32 out of 48 patients, remaining 16 cases were negative. There were no false positive results by PCR, out of 34 control cases none was tested positive for PCR. Thus, sensitivity of PCR 
Table No. 1

Diagnostic yield for pleural tuberculosis

\begin{tabular}{lcccc}
\hline $\begin{array}{l}\text { DIAGNOSTIC } \\
\text { VARIABLES }\end{array}$ & $\begin{array}{c}\text { ZN- } \\
\text { STAINING }\end{array}$ & $\begin{array}{c}\text { MANTOUX } \\
\text { TEST }\end{array}$ & ADA & PCR \\
\hline POSITIVE & 15 & 22 & 28 & 32 \\
\hline $\begin{array}{l}\text { SENSITIVITY } \\
(\%)\end{array}$ & 20 & 45 & 53 & 67 \\
\hline
\end{tabular}

for detection of tubercular pleurisy worked out to be $67 \%$ while specificity for the same was $100 \%$. These results suggest that the PCR is more sensitive than other co-existing conventional methods, but still not absolute to identify all cases. However, all ZN positive samples were found positive on PCR amplification. Our results were comparable with those of Delassence et al (5) who found PCR sensitivity of $60 \%$ in their patients of pleural tuberculosis. Our results were also consistent in respect of sensitivity and specificity with those of Querol et al (10) who had shown sensitivity and specificity of PCR in the diagnosis of pleural tuberculosis to be $81 \%$ and $100 \%$ respectively.

In our report, negative PCR results seen in 16 patients with pleural tuberculosis were either due to presence of inhibitors that are particularly high in pleural fluids (11) or due to sampling difficulties. The chance of detecting mycobacterium becomes higher with a bigger sample volume. Since, we had taken only 3-4 $\mathrm{ml}$ per patients, part had to be utilized for $\mathrm{ZN}$-staining and ADA, only $1-2 \mathrm{ml}$ was available for PCR. In view of the fact that delayed hypersensitivity is the underlying immune response in tubercular pleurisy, the pauci-bacillary state could be accounted for the false-negative results to some degree. However, whenever the result was positive, the mycobacterial load must have been sufficiently high.

Studies conducted by Parandaman $\mathrm{V}$ et al (12), Tan $\mathrm{J}$ et al (13), Takagi $N$ et al (14) and Jatana SK et al (15) show disparate results where sensitivity is $100 \%$ and specificity

Table No. 2

2 Specificity and Sensitivity of PCR in tubercular and other pleural effusions.

\begin{tabular}{c|l|c|c|c|c|c}
\hline $\begin{array}{l}\text { S. } \\
\text { No. }\end{array}$ & $\begin{array}{l}\text { PLEURAL } \\
\text { EFFUSION }\end{array}$ & $\begin{array}{c}\text { No. OF } \\
\text { PATIENTS }\end{array}$ & $\begin{array}{c}\text { PCR } \\
(+)\end{array}$ & $\begin{array}{c}\text { PCR } \\
(-)\end{array}$ & $\begin{array}{c}\text { SPECIFI- } \\
\text { CITY } \\
(\%)\end{array}$ & $\begin{array}{c}\text { SENSITI- } \\
\text { VITY } \\
(\%)\end{array}$ \\
\hline 1 & $\begin{array}{l}\text { TUBER- } \\
\text { CULAR }\end{array}$ & 48 & 32 & 16 & \multirow{2}{*}{100} & 67 \\
\hline 2 & $\begin{array}{l}\text { NON- } \\
\text { TUBER- } \\
\text { CULAR }\end{array}$ & 34 & none & 34 & 67 \\
\hline
\end{tabular}

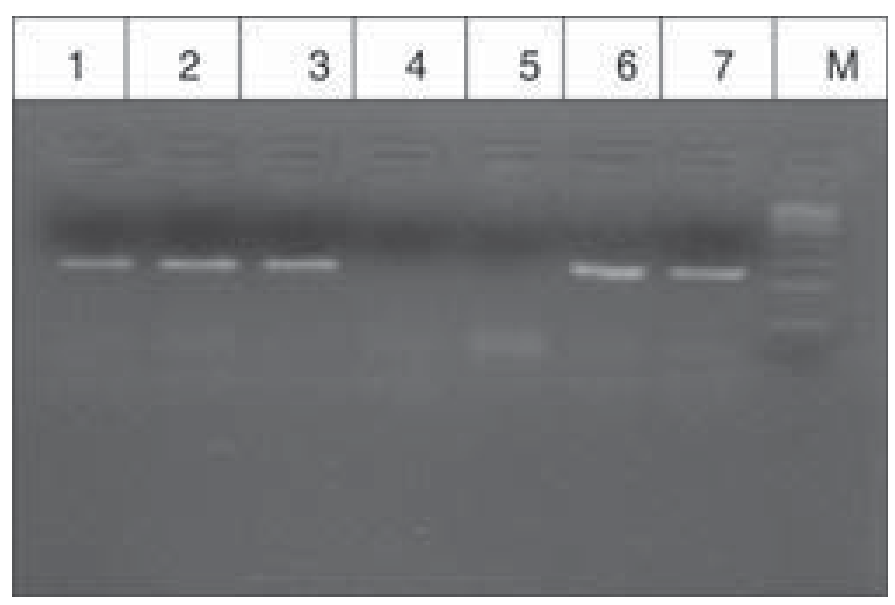

Fig. 1 PCR-based detection of Mycobacterium tuberculosis targeting MPB64 gene. Electrophoretic separation of the amplicon into $2 \%$ agarose gel is documented across Lanes 1-7. Lanes 1-3 represent the clinical pleural fluid samples, Lanes $4 \& 5$ exemplify the colony-PCR from atypical Mycobacterium (Mycobacterium bovis) and lanes 6 \& 7 stand for the colony-PCR from Mycobacterium tuberculosis culture of the clinical samples of tubercular pluirisy. The presence of a $240 \mathrm{bp}$. amplicon in the Lanes 1, 2, 3, 6 \& 7 indicated the presence of the target while the absence of the amplicon in the Lanes $4 \& 5$ pointed towards the absence of the target.

varied from $75-90 \%$. These studies have been carried out on a smaller sample size; all of them have targeted the insertion sequence IS6110 and have employed different set of primers. Moreover, a sensitivity of $100 \%$ and a low specificity means that all mycobacteria that are picked up by PCR are not necessarily Mycobacterium tuberculosis. This further lends credit to our study where the specificity is $100 \%$ and sensitivity is $67 \%$ implying that all the mycobacteria picked up by PCR targeting MPB64 gene are Mycobacterium tuberculosis; these results were further substantiated by colony PCR of various Mycobacterium species (Fig.1). Hasaneen et al (16) have reported that $93 \%$ sensitivity of PCR for pleural biopsy samples but the underlying invasive procedure makes it intricate to comply with. However, to further enhance sensitivity of PCRMPB64 together with the IS6110 targeted primers in a multiplex PCR- possibly will be the answer, where $100 \%$ sensitivity and specificity could be accomplished.

\section{REFERENCES}

1. Shinnick, T.M. and Jones, J. (1994) Molecular approaches to the diagnosis of tuberculosis. In: Bloom BR, ed. Tuberculosis; Pathogenesis, Protection and Control. Washington DC: American Society for Microbiology. 517530. 
2. Singh, R., Singh, R.S. and Tripathi, A.K.G. (2004) Circadian Periodicity of Plasma Lipid Peroxides and AntiOxidant Enzymes in Pulmonary Tuberculosis. Ind. J. Clin. Biochem 19, 14-20.

3. Fontan-B Buero, J.F., Hemando, Garcia-Buycla, J.P., Juneal, L.D.,Eganna, M.T.M. and Martinez, M.C.M.(1998) Diagnostic value of simultaneous determination of pleural adenosine deaminase and pleural lysozyme/serum lysozyme ratio in pleural effusions. Chest. 93, 303-310.

4. Valdes, L., Alvarez, D. and San Jose, E. (1998) Tuberculous pleurisy; a study of 254 patients. Arch Intern Med. 158, 2017-2021.

5. Pai, M., Flores, L.L., Riley, L.W. and Colford, J.M. (2003) Nucleic Acid Amplification tests in the diagnosis of tubercular pleuritis. BMC Infec Dis. 4, 6-11.

6. De Lassence, A., Lecossier, D., Pierre, C., Cadranel, J. and Stern, M. (1992) Detection of mycobacterial DNA in pleural fluid from patients with tuberculous pleurisy by means of the polymerase chain reaction; comparison of two protocols. Thorax. 47, 265-69.

7. Sritharan, V., Iralu, J. and Barker, R.H. Jr. (1994) Comparison of genus and species specific probes for polymerase chain reaction detection of mycobacterial infections. Mol Cell Probes. 8, 409-416.

8. Villena, V., Rebollo, M.J. and Aguado, J.M. (1998) Polymerase chain reaction for the diagnosis of pleural tuberculosis in immune-compromised and immunecompetent patients. Cl. Int. Dis. 26, 212-214.

9. Seth, P., Ahuja, G.K., Bhanu,V., Behari, M., Bhowmik, S., Broor, S., Dar, L. and Chakrobarty, M. (1996) Evaluation of PCR for rapid diagnosis of clinically suspected tuberculous meningitis. Tubercle and Lung dis. 77, 353357.
10. Querol, J., Minguez, J., Garcia-Sanchez, E., Farga, M.A., Gimeno, C. and Garcia-Lomas (1995) Rapid diagnosis of pleural tuberculosis by PCR. Am. Respir. Crit. Care. Med. 152, 1977-81.

11. Nagesh, S.B., Sehgal, S., Jindal, S.K. and Arora, S.K. (2001) Evaluation of PCR for detection of Mycobacterium tuberculosis in pleural fluid. Chest. 119, 1737-1741.

12. Parandaman, V., Narayanan, S. and Narayanan, P.R. (2000) Utility of polymerase chain reaction using two probes for rapid diagnosis of tubercular pleuritis in comparison to conventional methods. Ind. J. of Med. Res. 112, 47-51.

13. Tan, J., Lee, B.W., Lim, T.K., Chin, V.K., Tam, C.B. and Xia, J.R. et al (1995) Detection of M. tuberculosis in sputum, pleural and broncheoalveolar lavage fluid using DNA amplification of the MPB-64 protein coding gene and IS6110 insertion element. Southeast Asian. J. Troop. Med. Public Health. 26(2), 247-252.

14. Takagi, N., Hasegawa, Y., Ichiyama, S., Shibagaki, T. and Shimokata, K. (1998). Polymerase chain reaction of pleura biopsy specimens for rapid diagnosis of tuberculous pleurisy. Int. J. Tuberc. Lung. Dis. 2(4), 338-341.

15. Jatana, S.K., Nair, M.N., Lahiri, K.K. and Sarin, N.P. (2000) Polymerase chain reaction in the diagnosis of tuberculosis. Ind. Pediatr. 37 (4), 375-382.

16. Nadia, A., Hasaneen, M.E., Zaki, H.M.S. and Ahmad, S. El-Morsi (2003) Polymerase Chain Reaction of Pleural Biopsy Is a Rapid and Sensitive Method for the Diagnosis of Tuberculous Pleural Effusion. Chest. 124, 2105-2111. 